\title{
The Development of Process Skill Based Interactive Multimedia in Science
}

\author{
Syahril Fazal \\ Educational Technology \\ State University of Medan \\ Medan, Indonesia \\ syahrilfazal27@gmail.com
}

\author{
Mursyid \\ Educational Technology \\ State University of Medan \\ Medan, Indonesia
}

\author{
Sriadhi \\ Educational Technology \\ State University of Medan \\ Medan, Indonesia
}

\begin{abstract}
The process skill based interactive instructional multimedia was developed to teach students in learning Scince independently with the content, exercise, virtual laboratory and evaluation connected to the process skill. This study aims to produce a process skill based interactive multimedia which is properly used in learning Science and to know the increase in the learning outcome of students from the use of process skill based interactive multimedia in Science. This study belongs to a research and development which uses the $R \& D$ model by Borg and Gall and combined with the instructional design model by Dick and Carey. The result of the validation and trial process shows that the developed interactive instructional multimedia is in the criteria of very decent. This result indicates that the multimedia is proper to use in learning Science. The result of hypothesis testing indicates that there is a difference between the learning outcome students in Science that use a process skill based interactive multimedia and the learning outcome students in Science that use a presentation media powerpoint. Therefore, the process skill based interactive instructional multimedia is proper and effective used in learning Science.
\end{abstract}

Keywords-development; interactive multimedia; process skill; science

\section{INTRODUCTION}

One of individual needs to develop self competence is education. It is connected to the Law of the Republic of Indonesia No. 20 year 2003 about national education system in article 1 section 1 which says that education is a conscious and planned effort to create a learning condition and instructional process in order to make students can develop their self competence actively to have religious spiritual strength, self control, character, smartness, good attitude and the skill which is needed by themselves, society, nation and country.

Purwanto [11] added that education is people's effort to cultivate their personality based on the values in society and culture. Then, Djamarah [3] views education as a conscious purposeful effort to develop the quality of human as a purposeful activity, so in the implementation, it is in a continuous process in every kind and level of education and all of them are connected each other in an integral and integrated education system.
A professional person who can create the main purpose of education is teacher, as it is written in the Law No. 14 year 2005 that teacher is a professional educator who has main duty to educate, teach, guide, direct, train, assess and evaluate the students in education through formal way in the basic and intermediate education. Beside that, to improve students' motivation in learning, teachers should produce learning source and deliver it attractively. It is also written in the National Education Ministrial Regulation of the Republic of Indonesia No.16 year 2007 about the standard of academic qualification and teachers' competence [7].

Curriculum of 2013 becomes one of goverment's supports to improve the quality of education, as it is written in the Education and Culture Ministrial Regulation No. 58 year 2014 that curriculum of 2013 was developed with the theory of standard-based education and competency-based curriculum [8]. Standard-based education establishes the existence of national standard as the minimum quality of people which is classified into standard of content, standard of process, standard of graduate competence, standard of teachers, standard of tools and infrastructure, standard of management, standard of budgeting, and standard of education assessment. Whereas in competence based curriculum was designed to give a wide experience of learning for students in developing their skill to do, have knowledge, have skill and to act.

Curriculum of 2013 uses taught curriculum in the developed process like the learning activities at school, classroom, and society. Learned curriculum is based on the background of students' characteristic and entry behavior. Learned curriculum becomes the learning outcome for themselves, while the learning outcome of all students becomes the result of curriculum. The porpose is to prepare people with life skill as an individual and a productive, creative, innovative and effective nation.

Commonly teachers always show verbalistic in Science, but actually Science is one of major subjects in curriculum of 2013 which aims to understand the nature to be conserved and protected in the views of Biology, Physics, and Chemistry. One of the expected competences in learning Science in the level of Junior High School is to understand the natural 
phenomenon based on the result of learning Science integratively through the specific fields such as Biology, Physics, and Chemistry. Learning Science is conducted by connecting it to a certain field. For example, while learning substance (Physics), the discussion is connected to an effort of human to breath (Biology) and a substance produced by respiratory system (Chemistry).

Acording to Isyarotullatifah [4], the fact, concept, principal, and law which got validity test through the assessment of a science about nature frequently and the development related to natural phenomenon is called Science. Then, Afrizon (2012: 4) said that the level of Junior High School learns Science in direct application and uses process skill and scientific attitude to develop science, technology, environment and society.

According to Rekayana [12], learning Science has a purpose to know environment and conduct scientific inquiry to create thinking skill, do, act scientifically, adapt and communicate to the surrounding.

To get an optimal learning outcome for students and to help students in doing their task well, then a teacher must have an ability and skill to master the content, deliver it and evaluate the learning process. The use of instructional media is very helpful because one of the main functions of instructional media is a tool in teaching that can affect the climate, condition and learning environment which has been managed by the teacher [1]. Therefor, the choosing of instructional media can be based on the learning objectives and the characteristic of the media.

Based on the observation in SMP Negeri 2 Bireuen, the portfolio of Science teacher said that the average mark of students grade VII in 2014/2015 is 55.0, in 2015/2016 is 53.70 and in 2016/2017 is 62.26, with the standard mark is 65 . It can be concluded that the students' mark in Science is still low and there was no significant improvement in each year. Then, the researcher found that the Science laboratory at that school is bad enough, so the students can not do experiment in some matters. They can not also take part in the instructional process actively. The researcher thought that it is caused by the instructional system which still uses text book and the teachers can not develop instructional media like powerpoint. It gave bad impact to the students' interest in learning Science.

Jufri [5] also found that there are a few teachers who have good understanding about teaching Science and inquiry as the components of Science that should be understood by students in intermediate level. In fact, the conventional model is still used by teachers through the method of memorizing the concept and the scientific fact. It makes the instructional process be monotonous and uninteresting.

The developed instructional media does not only attract the students' interest, but also it must improve their skill in learning. Science is a learning which interacts directly to the nature. Students must have process skill. Process skill is a skill which is used to obtain and discuss the natural phenomenon.
Process skill includes: observation, prediction and explanation.

Based on the result of research and development done by Suniati [14] said that using interactive multimedia is a solution to make students be easy in understanding Science. The students do not only focus on the media or the object but also interact during the instructional process.

Based on the background above, to improve the instructional process which can improve the learning outcome, interest, creativity and understanding of students related to the learning content by using the available facilities, then one solution that the researcher offered to SMP Negeri 2 Bireuen is to develop process skill based interactive multimedia in Science.

\section{METHOD}

This research and development was conducted in SMP Negeri 2 Bireuen in Jl. Banda Aceh - Medan Desa Geulanggang Baroe, Subdistrict of Kota Juang, Regency of Bireuen, Province of Aceh toward the students grade VII in learning year of 2018/2019. This research was started by doing observation in the school to know the condition of the students, the educational background of the teachers and the facilities in the school. This research and development was conducted for 5 months (from January until May 2019). It was started from the step of designing, developing the media, validity of experts, trial, and the effectiveness test

This research belongs to Research and Development (R\&D). Research and development model is a research method which produces a product and to test the effectiveness of the product.

There are five steps in the procedure of development which must be done to produce the interactive multimedia in learning Science in the topic about the system of life organization for students of SMP Negeri 2 Bireuen by using the development model of Borg \& Gall [2]. They are: (1) Preliminary, this step includes library research and observation at the school. The libarry research is conducted to find out information about the development of interactive multimedia in learning Science. The observation is conducted to get information about the condition, facilities, infrastructure, and the learning process at the school. Then to identify the students' characteristic and entry behavior, identify the syllabus and find out the problem in the learning process. (2) Planning, this step was started by compiling the learning content based on the needs. The content is about the system of life organization. Then, design the standard of competence, learning indicators, topics, sub-topics and the learning objectives. The next, compile the lesson plan and the research instrument. (3) Product development, it was started by collecting the materials, making flowchart view and storyboard, entering the learning content into the software and documenting it into CD. (4) Review and trial to revise the product, in this step, the first development was validated by the media experts and the content experts, revising I, then 
conducting small group trial, revising II, field trial, revising III, students' reflection, revising IV to produce the final product which is an interactive multimedia in learning Science based on the need and the expected objectives. (5) the last step, conducting the effectiveness test to know the effectiveness of the final product.

The data analysis in testing the validity of the interactive multimedia in learning Science used quantitative analysis. The quantitative data such as: very good, good, enough, poor and very poor was changed into the scale of 1 to 5 . The criteria of experts' assessment used Likert Scale which was analyzed descriptively by using the pattern below:

$$
\pi=\frac{\sum X}{n}
$$

Explanation:

$$
\begin{array}{ll}
x & : \text { The average score } \\
\mathrm{\Sigma X} & : \text { The total score } \\
\mathrm{n} & : \text { The maximum score }
\end{array}
$$

The criteria of the assessment was adopted from Sriadhi [13] as it can be seen in table 1 .

TABLE 1. THE CRITERIA OF ASSESSING THE INTERACTIVE MULTIMEDIA

\begin{tabular}{|c|c|c|}
\hline No. & Interval Mean Score & Criteria \\
\hline 1 & $1.00-2.49$ & Improver \\
\hline 2 & $2.50-3.32$ & Proper Enough \\
\hline 3 & $3.33-4.16$ & Proper \\
\hline 4 & $4.17-5.00$ & Very Proper \\
\hline
\end{tabular}

The analysis technique in the effectiveness test used descriptive technique. Decriptive technique is a statistic which is used to analyze the data by describing the collected data purely without making conclusion for the generalisation. Before conducting one way t-test (hypothesis test), the data must be normal and homogenous. To test the data normality, it used Liliefors test. Then, to test the data homogeneity, it used Fsher test.

\section{RESULT AND DISCUSSION}

\section{A. The Result of Validity Test toward the Product}

Based on the result of validity test, the process sikill based interactie multimedia in learning Science is proper to be used as instructional media. The assessment of content experts was in the score of 4.46 and it means that the media is proper to be used as media in learning Science because it contains of matter and the criteria of delivery system has fulfilled the standard of delivery system toward students. The instructional design experts gave score of 4.50 and it means that the interactive multimedia is proper to be used because it has been designed well and it has fulfilled the standard of instructional design. The media experts gave score of 4.62 and it means that the interactive multimedia is proper to be used as an instructional media because it has fulfilled the principals and criteria of developing the instructional media. The result of individual trial gave score of 4.61 and it means the interactive multimedia is proper to be used in learning Science. The result of small group trial gave score of 4.70 and it means that the interactive multimedia is also proper to be used in learning Science. Then, the result of field trial gave score of 4.78 and it means that the interactive multimedia is proper to be used as instructional media.

Based on the result of validity and trial test, then the process sikill based interactive multimedia in learning Science is very proper to be used in learning Science. Therefore, the media is very proper to improve the effectiveness of the instructional process, especially in learning Science. Puji [10] also said that interactive multimedia can help students in instructional process and it can attract the students' interest so they can remember the matter easily.

\section{B. The Result of Effectiveness Test toward the Product}

The effectiveness test toward the process sikill based interactive multimedia in learning Science was conducted by comparing the average of students' learning outcome that are taught by the developed interactive multimedia to the ones that are taught by Powerpoint. Both data was analyzed by using non-parametric statistic. It was because both data did not fulfil the requisite to do parametric statistic. Both data was not homogenous.

Based on the data processing, there was a better improvement in the Science learning outcome of students who are taught by using the process sikill based interactive multimedia than the ones who are taught by Powerpoint. It was because the Science learning outcome of students who are taught by the process sikill based interactive multimedia was higher than the ones who are taught by Powerpoint.

Science is knowledge which is obtained through investigation by doing observation, prediction and experiment. Science is a subject which learns the nature with the things on the earth, in the earth and on the space. In developing this multimedia, the researcher controlled the students by giving an experiment of virtual laboratory.

The students' process skill was run by observing the tools and materials, then predicting the things should be done, and the students did a simple practice. After finishing the processes, the students were asked to communicate the result to the others with teacher's direction. Turiman [16] said that the development of science and technology in the digital era can develop students' skill through literacy skill and science process especially for the science students. Multimedia gives a good impact toward students in which they can explore the new concepts that are close to students' daily life and they can explain the concept of science well. So, multimedia can improve the students' interest in learning Science and it makes the instructional process runs effectively.

A teacher is also an important factor to make the success of learning process beside the developed multimedia. The 
developed media is a supporting tool for teacher to explain the learning content to the students. Therefore, learning Science does not only memorize the theory but also understand the concept and give priority to the process. Teacher helps students to learn finding information. Supardi [15] said that the role of teacher is very important in the instructional process, so the developed instructional media does not only explain from one side. The interaction between teacher and student is expected to improve the students' interest in learning.

The developed interactive multimedia has a virtual laboratory which contains of a simple practice to investigate the cell of plants by using microscope. This feature provides guidance and steps to do the experiment which is almost same with the experiment done in the Science laboratory. This feature can make teacher direct an experiment more easily and the students also feel easy to do the experiment and observe the cell by using a clear visual. It proves the statement of Nopriyanti [9] who said that the simple simulation can be presented by using Adobe Flash CS3 so the students can understand the matter easily because it is presented in multimedia which has been developed.

The developed interactive multimedia is effective to be used in learning Science and it proves the statement of Kareem [6] who said that the use of multimedia in learning Biology has a positive impact toward the students' learning outcome. The learning content which is presented in multimedia is more effective and more understandable. The use of multimedia in learning is more interesting and it can help students to develop positive attitude toward Biology learning so it can improve students' interest.

It can be seen through the average of Science learning outcome of students who are taught by using the process skill based interactive multimedia which is in the score of $83.85 \%$. However, the average of Science learning outcome of students who are taught by using Powerpoint only got score of $76.67 \%$. It indicates that the use of the process skill based interactive multimedia is more proper and effective to improve the competence, knowledge, and skill of students in learning Science than the use of Powerpoint.

\section{CONCLUSION}

Based on the problems, objectives, result and discussion of this study, then it can be concluded that: (1) The process skill based interactive multimedia in learning Science for students grade VII at SMP Negeri 2 Bireuen is proper as the final product that can be spreaded out and implemented toward students as the users. All the assessment results in the validity and trial test got the average of 4.64 in the category of "very proper". (2) The average of students' learning outcome that learned by using the process skill based interactive multimedia in learning Science was higher than the average of students' learning outcome that learned by using Powerpoint $(83.85 \%>$ $76.67 \%$ ). It indicates that the process skill based interactive multimedia in learning Science is effective to improve the students' learning outcome.

\section{REFERENCES}

[1] Arsyad, A. (2009). Media Pembelajaran. Jakarta: PT. Raja Grafindo Persada.

[2] Borg, W. R.,\& Gall, M. D. (1983). Educational Research: An Introduction. New York: Longman.

[3] Djamarah, S. B. (2005). Guru dan Anak Didik dalam Interaksi Edukatif. Jakarta: PT. Rineka Cipta

[4] Isyarotullatifah., Agung, G. A., \& Luh P. P. M.(2015). Pengembangan E-Learning dengan Model Waterfall pada Mata Pelajaran IPA Di SMP Negeri 1 Singaraja. Jurnal Edu-Tech, 3(1), 1-10.

[5] Jufri, A. W.,\& Hikmawati. (2014). Analisis Kemelekan Sains (Science Literacy) dan Kemelekan Inkuiri (Inquiry Literacy) Guru Mata Pelajaran IPA SMP. Jurnal PIJAR MIPA, 9(1), 9-14.

[6] Kareem. A. A. (2018). The use of Multimedia in Teaching Biology and Its Impact on Students' Learning Outcomes. In Shelley, M., \& Mustafa The Eurasia Proceedings of Educational \& Social Sciences(pp. 157165). Turkey, International Conference on Education in Mathematics, Science and Technology (ICEMST). Diakses dari dergipark.gov.tr/download/article-file/531778

[7] Kementerian Pendidikan Nasional. (2007). Peraturan Menter Pendidikan Nasional Republik Indonesia Nomor 16 Tahun 2007 tentang Standar Kualifikasi Akademik dan Kompetensi Guru. Jakarta: Kemendiknas.

[8] Kementerian Pendidikan dan Kebudayaan. (2014). Peraturan Menteri Pendidikan dan Kebudayaan Nomor 58 Tahun 2014 Tentang Kurikulum 2013 Sekolah Menengah Pertamal Madrasah Tsanawiyah. Jakarta: Kemendikbud.

[9] Nopriyanti.,\& Putu, S. (2015). Pengembangan Multimedia Pembelajaran Interaktif Kompetensi Dasar Pemasangan Sistem Penerangan dan Wiring Kelistrikan di SMK. Jurnal Pendidikan Vokasi, 5(2), 222-235.

[10] Puji, K. M., Fakhili, G., \& Ibrahim. A. R. (2014). Pengembangan Multimedia Interaktif untukPembelajaran Bentuk Molekul di SMA. Jurnal Penelitian Pendidikan Kimia, 1(1), 59-65

[11] Purwanto. (2009). Evaluasi Hasil Belajar. Yogyakarta: Pustaka Pelajar.

[12] Rekayana, I. W., Wayan, K., \&Gede, A.(2013). Pengembangan Multimedia Interaktif pada Mata Pelajaran IPA Kelas VII Semester II di SMP Negeri 5 Tejakula Tahun Pelajaran 2012/2013. Jurnal Edu Tech, $1(2), 1-10$.

[13] Sriadhi. (2018). The Effect of Tutorial Multimedia on the Transformator Learning Outcomes Based on the Students' Visual Ability. IOP Conference Series: Materials Science and Engineering, 384 (012059): $1-5$.

[14] Suniati, N. M. S., Wayan, S.,\& Anggan S.(2013). Pengaruh Implementasi Pembelajaran Kontekstual Berbantuan Multimedia Interaktif Tehadap Penurunan Miskonsepsi (Studi Kuasi Eksperimen dalam Pembelajaran Cahaya dan Alat Optik di SMP Negeri 2 Amlapura). Jurnal Administrasi Pendidikan, 4(1), 1-13

[15] Supardi, U.S., Leonard, Huri, S., \& Rismurdiyati. (2012). Pengaruh Media Pembelajaran dan Minat Belajar terhadap Hasil Belajar Fisika. Jurnal Formatif, 2(1), 71-81

[16] Turiman, P., Omar, J., Daud, A. M., \& Osman, K. (2012). Fostering the $21^{\text {st }}$ Century Skills through Scientific Literacy andScience Process Skills. Procedia- Social and Behavioral Sciences, 59(2012), 110-116. 